\title{
Secular score gains on Raven's Progressive Matrices in a population of Polish adolescents
}

\begin{abstract}
The paper presents findings on secular score gains in Raven's Progressive Matrices during six decades (19482009) in Polish adolescents. Seven groups are being compared, comprising of 20, 490 subjects in total. The representative groups examined in $2000(N=1,331)$ and $2009(N=3,650)$ are those of special interest as they are the most numerous and allowing formal means comparison using standard test for comparison of means and Welch's test. Possible causes for the noted effect are being discussed, with special emphasis on the economic growth and its implications - such as improved nutrition, education changes, growth of adolescent's well-being and child upbringing practices.
\end{abstract}

Key words: Flynn effect, Flynn-Runquist effect, intelligence, Raven's Progressive Matrices variation

\section{Introduction}

The so called "Flynn effect" designating regular and systematic worldwide increase of mean results in standardized intelligence test performance, observed since the beginning of the 20th century (Flynn, 1984; Flynn, 1987) is believed to be first observed by the New Zealand political scientist, James Flynn. Based on analysis of data from 14 different countries (Flynn, 1987), a considerable increase in intelligence test scores of 5 to 25 point on deviational intelligence quotient scale for each generation has been demonstrated. As recently reported by Lynn (2013) in his work "Who discovered the Flynn effect?", the notion "Flynn effect" was used for the first time by Herrnstein and Murray (1994, p. 307), but in fact this effect was described by Runquist almost half a century earlier (Runquist, 1936). In an attempt to take into account this recent consideration by Lynn (2013) on long forgotten Runquist (1936)'s discovery, a decision was made to coin the term "FlynnRunquist effect" in this work for the phenomenon made widely recognized under the name "Flynn effect".

The rise of scores is usually found to be greater on tests of fluid intelligence, such as Raven Progressive Matrices (Brouwers, Van de Vijver and Van Hemert, 2009), than on tests of crystallized intelligence, especially nonverbal IQ tests (Flynn, 1987; Teasdale \& Owen, 2000, Wicherts et al., 2004). However, a considerable increase is recorded also for tests measuring crystallized intelligence such as Similarities scale in Wechsler's Intelligence Test. In general, the results raise the lower compartment of the distribution, while the results of the talented people are not increased at the same rate.

Ever since the existence of this phenomenon was announced, there has been an intense discussion on the nature, the causes and the implications of this change (Neisser, 1998; Wicherts, Dolan, Hessen, Oosterveld, van Baal, Boomsma, Span, 2004). Still, there is no consensus on the interpretation of several issues concerning the nature of the observed secular score gains.

Flynn (2007) explains this paradox by referring to more specific skills necessary to cope with various tests, and thus - to what the specific skills society considers as particularly valuable and worth developing. Flynn (2007) suggests that much can be explained by a gradual shift from pre-scientific mode of thinking, in which the learner is given the principles that ought to be used in the problemsolving thinking, to scientific mode of thinking that requires the use of higher levels of general and immediate resolution problems. Dissemination of scientific thinking can result in

\footnotetext{
* The Maria Grzegorzewska, Academy of Special Education, Applied Psychology Institute, 02-353 Warsaw, Poland, ul. Szczęśliwicka 40, ewa.m.witkowska@wp.pl
} 
detachment from the concrete and becoming more flexible, and thus - more efficient in the way of thinking. According to Flynn (2007), this is what can improve performance even in such a test as Similarities. As suggested by Flynn (2007) in his book "What is intelligence? Beyond the Flynn effect", the observed need for the increase in performance may soon stop. It seems that in Scandinavia it is already happening, while in the United States the trend continues. And in Switzerland, an effect opposite to the Flynn's (Nicollet, Guillen, Jouhar and Rossier, 2009) has been recently found. Based on the ability test results collected for over 10 years - in 1991 and 2002, a heterogeneous trend opposite to the Flynn-Runquist effect was observed: a decline in school performance testing capabilities - which measure verbal and numerical abilities.

In the secular score gains literature, two questions seem to be of special importance - one of whether the observed increases are related to an increase in the general intelligence (i.e. Flynn, 2000, Rushton, 2000) and the second - of whether it can merely reflect measurement artifacts (Flynn, 1990). Although recorded to a bigger extent in case of culturally reduced tests, the occurrence of the Flynn-Runquist effect has been predominantly seen as the result of environmental factors (Wicherts et al., 2004; Lynn, 1990; Martorell, 1998; Zajonc \& Mullally, 1997; Husen \& Tuijnamn, 1991; Teasdale \& Owen, 1989; Tuddenham, 1948; Schooler, 1998). There are several hypotheses explaining the Flynn-Runquist effect, but none of them seems comprehensive and unquestionable. In the literature there are several explanations: the "familiarity hypothesis" referring to a wider contact with tasks similar to those in intelligence tests due to educational practices, referring to shift in interest in solving specific mental tasks, the Brand hypothesis (Brand, 1987) referring to improved nutrition (Lynn, 1990; Martorell, 1998) and living conditions.

The widely known Brand hypothesis (1987) claims that test-taking strategies affect test scores. One of the reasons may be proneness to guessing that has been more frequent nowadays then it used to be. The use of this strategy results in higher scores on multiple-choice tests (Wicherts at al, 2004) such as Raven's Progressive Matrices Test.

The "familiarity hypothesis" pertains to the fact that television, computer games, puzzles, and/or solving logical tasks significantly enhance information delivered in iconic form, making the observed environment much more complex than a few decades ago. IQ tests that measure intellectual ability unrelated to cultural influences are based just on the analysis of visual material. Therefore, the increased visual training increases the ability to solve these tests.

This hypothesis says that only the increase in people's skills in dealing with typical intelligence tests is observed rather than the increase of the intelligence of the population as such. According to this explanation, the observed increase in the intelligence would be an artifact. However, it appears that the Flynn-Runquist effect was also present at the times when neither computers nor television were so widespread.
In their cross-cultural and historical metaanalysis of Raven's Progressive Matrices scores, based on 798 samples from 45 countries $(N=244,316)$ published between 1944 and 2003 Brouwers, Van de Vijver and Van Hemert (2009) emphasize that the Flynn-Runquist effect is an implication of country-level indicators of educational permeation, strongly related to economic development.

According to Martorell (1998), nutritional improvements in industrialized countries can account for the Flynn-Runquist effect. The author perceives the mean height increase as an indicator of proper nutrition and on the basis of an examination of secular trends in height in industrialized countries he concludes that the observed tendencies are similar as secular intelligence test gains and therefore cannot be seen as independent. Moreover, referring to the studies of intellectual performance in undernourished children from developing countries, the role of nutrition in fetal life, early childhood and at school ages he concludes that better nutrition during all these critical periods contributes to better intelligence test performance. As there has been no systematic research on the FlynnRunquist effect in Poland before, and the existing works (i.e. Lynn, 2013) are based on ability measures not longer being used, such as the Otis test, this work aims to determine whether in the Polish population, this effect may be observed in mean results of the culturally reduced and therefore universal Raven's Matrices Test.

\section{Method}

This study is based on comparison of means of the Raven's Progressive Matrices Test (Jaworowska \& Szustrowa, 2000) in seven Polish samples, examined in 1948, 1952, 1970, 1971, 1974/75, 2000 and 2009. The Raven's Progressive Matrices Test (Jaworowska \& Szustrowa, 2000) is one of the most widely used culturally reduced tests in the world. It was claimed (Jaworowska \& Szustrowa, 2000) that the Raven Matrices test is one of the best measures of Spearman's $g$ factor. Flynn (1987) emphasizes that in the case of this measure, the items cannot be easily learned from one generation to another and the test material remained unaltered for years (Jaworowska \& Szustrowa, 2000). According to a systematic review of Polish studies on Raven's Progressive Matrices prepared by Jaworowska (1990), all considerable studies have been therefore covered. As in Poland there was no official register of intelligence test scores alike those of military service or education system, where intelligence tests data can be traced, and therefore the historical data that originated mainly from scientific studies (Hornowski, 1959; Stryżewski, 1973; Jaworska, 1976) is limited either geographically (i.e. Firkowska-Mankiewicz, Ostrowska, Czarkowski, 1978 study of youth from Warsaw and vicinities) or with regard to the sample size, it has been decided to compare means formally for the recent studies - Polish Standardization 2000 (Jaworowska \& Szustrowa, 2000) and National Study of Polish Adolescents 2009 (Smulczyk, Haman, Pokropek, in press) and to compare other incidental groups against the last one where it is possible. The newer studies - of 2000 and 
Ewa Witkowska

2009 are more representative. The study of 2009 derivates from Polish Standardization of Raven's Progressive Matrices and for the chosen age groups it refers to data for 1,331 individuals (Jaworowska Szustrowa, 2000). The newest of the described studies originates from the National Study of Polish Adolescents and covers the sample of 3,650 adolescents. The National Study of Polish Adolescents was conducted in November 2009. This representative survey as an entirety was carried out on a sample of approximately 4,000 individuals. The study was conducted in various schools with participation of 16 and 17-year-old students.

\section{Results}

All incorporated studies have been divided into two groups - the earlier studies, tracing back to 1948 (Hornowski, 1959) but limited in sample size (Hornowski, 1959; Stryżewski, 1973) and representativeness as they were performed in Polish big cities such as Warsaw, Poznan or Bydgoszcz (Hornowski, 1959; Stryżewski, 1973; Jaworska, 1976, Firkowska-Mankiewicz, Ostrowska, Czarkowski, 1978) and the recent representative studies - the Polish Standardization 2000 (Jaworowska \& Szustrowa, 2000) and the National Study of Polish Adolescents 2009 (Smulczyk, Haman, Pokropek, in press). Information on group means, standard deviations and samples sizes for the earlier studies are presented in Table 1, whereas Table 2 specifies the recent studies. General mean score changes trend in time is presented on Figure 1.
Due to the sample size and data completeness in each group, the formal comparison of means was performed for the recent studies: the Polish Standardization 2000 (Jaworowska \& Szustrowa, 2000) and the National Study of Polish Adolescents 2009 (Smulczyk, Haman, Pokropek, in press). This formal comparison of means was performed for four age levels $(15.6-16.5,16.6-17.5,17.6-18.5,18.6-$ 19.5) separately. The research groups comprised of 1,331 and 3,650 subjects, respectively. Although there were only nine years elapsed time between these studies, there was a considerable score increase for three out of four groups: 15.6-16.5, 16.6-17.5, and 17.6-18.5 years. Mean score gains of 14.78 points (age: 15.6-16.5, $N=28$ ), 6.52 points (age: 16.6-17.5, $N=2,161$ ), 5.97 (age: 17.6-18.5, $N=1,357$ ) were observed. For the oldest group (age: 18.6-19.5) the mean score decrease of 3.22 was noted, however the latter decrease is not statistically significant contrary to the observed increases, which are statistically significant assuming a reasonable significance level.

To summarize, the results indicate that in case of the Raven's Progressive Matrices results the Flynn-Runquist effect is observed in the Polish population. The steady score gains are not only observed in long term but also within one decade.

Table 1. Changes of mean results in Raven's Progressive Matrices - earlier studies

\begin{tabular}{|c|c|c|c|c|c|c|c|c|c|c|c|c|c|c|c|}
\hline \multirow[t]{2}{*}{ Age } & \multicolumn{3}{|c|}{$\begin{array}{c}1948, \\
\text { Poznań sample } \\
\text { (Hornowski, 1959) }\end{array}$} & \multicolumn{3}{|c|}{$\begin{array}{c}1957 \\
\text { (Kalina, 1962) }\end{array}$} & \multicolumn{3}{|c|}{$\begin{array}{c}1970, \\
\text { Bydgoszcz sample } \\
\text { (Stryżewski, 1973) }\end{array}$} & \multicolumn{3}{|c|}{$\begin{array}{c}1971, \\
\text { Warsaw sample } \\
\text { (Jaworska, 1976) }\end{array}$} & \multicolumn{3}{|c|}{$\begin{array}{c}1971, \\
\text { Warsaw sample } \\
\text { (Jaworska, 1976) }\end{array}$} \\
\hline & $M$ & $S D$ & $N$ & $M$ & $S D$ & $N$ & $M$ & $S D$ & $N$ & $M$ & $S D$ & $N$ & $M$ & $S D$ & $N$ \\
\hline $11-12$ & - & - & - & - & - & - & - & - & - & - & - & - & 36.05 & 10.39 & 13,695 \\
\hline $15 ; 6-16 ; 5$ & 32.5 & 9.7 & 236 & - & - & - & 43.36 & 7.66 & 224 & - & - & - & - & - & - \\
\hline $16 ; 6-17 ; 5$ & - & - & - & - & - & - & - & - & - & - & - & - & - & - & - \\
\hline $17 ; 6-18 ; 5$ & - & - & - & - & - & - & - & - & - & 38.5 & 6.5 & 511 & - & - & - \\
\hline $18 ; 6-19 ; 5$ & - & - & - & - & - & - & - & - & - & - & - & - & - & - & - \\
\hline Adults & - & - & - & 47.5 & 4.5 & 843 & - & - & - & - & - & - & - & - & - \\
\hline
\end{tabular}

Table 2. Changes of mean results in Raven's Progressive Matrices - recent studies

\begin{tabular}{lccccccc}
\hline \multirow{2}{*}{ Age } & \multicolumn{4}{c}{ Polish Standardization 2000} & \multicolumn{2}{c}{$\begin{array}{c}\text { National Study of Polish } \\
\text { Adolescents 2009 }\end{array}$} & $\begin{array}{c}\text { Test for comparison } \\
\text { of means }\end{array}$ \\
\cline { 2 - 7 } & $M$ & $S D$ & $N$ & $M$ & $S D$ & $N$ & $21.07 * *$ \\
$15.6-16.5$ & 41.4 & 5.86 & 376 & 56.18 & 3.35 & 28 & $21.07 * *$ \\
$16.6-17.5$ & 42.1 & 5.45 & 364 & 48.62 & 7.46 & 2161 & $19.09 * *$ \\
$17.6-18.5$ & 42.3 & 6.39 & 343 & 48.27 & 7.46 & 1357 & $14.92 * *$ \\
$18.6-19.5$ & 44.0 & 5.56 & 248 & 40.78 & 9.58 & 104 & -3.21 \\
Total & & & 1,331 & 48.32 & 7.64 & 3,650 & -3.21 \\
\hline
\end{tabular}


As argued by Flynn (1987), the studies analyzing secular ability tests changes should use mature subjects, who have reached the peak of their performance before being examined. It would allow for elimination of the possibility that the younger cohort simply reaches this peak earlier and in the moment of full maturity there will be no differences in these groups' mean score. However, Flynn (1987) himself does not comply with this rule. It case of this study, its application would also be very difficult, because most studies on larger samples were carried out with the participation of adolescents. However, on the basis of the existing data it is impossible to decide whether the observed result is a real perceptual ability increase or it indicates only the developmental shift in this domain of cognitive abilities.

Figure 1. General mean score changes on Raven's Progressive Matrices trend in time

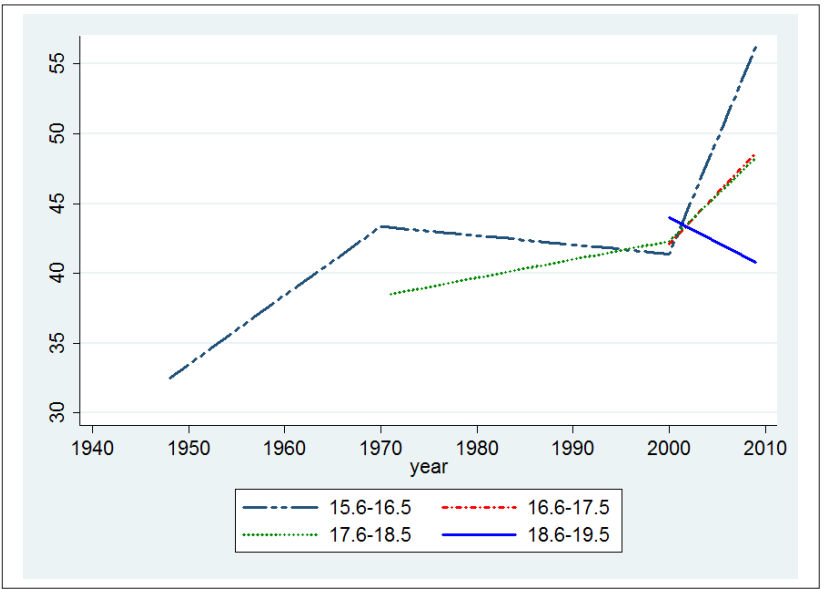

\section{Conclusions}

The results of this study provide another argument for the existence of the Flynn-Runquist effect. The comparison on secular score gains itself is sufficient for confirmation of the existence of the effect in the Polish population although it is insufficient for understanding of its causes. The Flynn-Runquist effect gains are predominantly perceived as driven by environmental factors (e.g. Nijenhuis $\&$ van der Flier, 2013). It seems that this general statement is also true for the Polish population and when one analyzes the sixty-year period, for a country undergoing such dramatic social and economic changes as Poland experienced during this time, such argument may be even more viable.

As Brouwers, Van de Vijver and Van Hemert (2009) claim in conclusion of their meta-analysis of 244,316 subjects from 45 countries, the Flynn-Runquist effect is an implication of country-level indicators of educational permeation, strongly related to economic development. They conclude that this effect can be observed in high as well as low GDP countries, although its size is moderated by education-related sample and country characteristics and seems to be smaller in the developed countries than in the emerging ones. This is in line with the economic research in the field of economic growth convergence, according to which less developed countries are expected to experience higher rate of progress (Próchniak \& Witkowski, 2013) and pertains to Poland and other Eastern European countries.

But not only should the economic factors be considered. Socioeconomic changes over these 60 years have their impact on change in the upbringing and educational practices of Poles. It manifests itself mainly in relation to corporal punishment, amount of time spent together by children and parents and the importance attached to education in succeeding generations. The awareness of the importance of parent-child relationship has increased considerably. These changes continue to act; a marked example is the ban on the use of corporal punishment adopted in Poland in 2010. Although still higher than in the Western European countries, there is constant and stable decrease in acceptance for corporal punishment in Poland (Sajkowska, 2009). Corporal punishment and other forms of childhood maltreatment (i.e. humiliation, emotional neglect) are associated with poor cognitive outcomes (Cicchetti \& Valentino, 2006; Jaffee \& Maikovich-Fong, 2011) as well as school adaptation problems and maladaptive development. When examining the association between child maltreatment and long-term cognitive outcomes within a prospective birth cohort, Mills and his colleagues (2011) noted that abuse and neglect are independently associated with lower perceptual reasoning. In their sample of 3,796, examined in the age of 14 , they noted mean difference of -4.8 points on Raven's Progressive Matrices score (when the standard deviation is $15)$.

According to Martorano, Natali, Neubourg and Bradshaw (2013) working paper on child well being, there are signs that the countries of Central and Eastern Europe, including Poland, are beginning to close the gap with the more established industrial economies. In these years, the percentage of children and adolescents in economically deprived countries decreased by 20 per cent. This may be one of the major factors accounting for the observed Raven's Progressive Matrices mean score increase between 2000 and 2009.

Better nutrition, i.e. eating fruit every day as it was reported by Martorano, Natali, Neubourg, Bradshaw (2013), may also account for the result increase during last decade. It will be even more intense in the previous decades when Polish economic situation and nation wealth have been growing and changed dramatically with systemic transition initiated in 1989. In his recent work, Lynn (2013) emphasizes that nutritional improvement accounts for changes in test performance to the biggest extent.

Husen and Tuijnman (1991) point to importance of formal schooling as one of the causes of the Flynn-Runquist effect. Although the situation in Poland is not perfect when thinking about cultural capital of children of low socioeconomic status and dismantling education barriers, especially in rural areas has not been completed, one shall point to the lowering of age of compulsory education (including compulsory preschool in age of 5). Comparison of the results of the OECD PISA study in 2006 and 2000 indicate a general improvement in the quality of education in Poland. It also shows that the problem of segregation resulting in substantial disparities in the quality of education 
still exists and the social and economic status of parents has a marked effect on results, more so than in most other countries (OECD PISA 2006).

Obviously, the above stated possible explanation requires further research. It would be especially important to systematically compare the results and economic condition of two subsequent generation but non-aggregated data is necessary to do so.

\section{References}

Brand, C. R. (1987). Bryter still and Bryter? Nature, 328, 110.

Brouwers, S.A., Van de Vijver, F.J.R., Van Hemert, D.A. (2009). Variation in Raven's Progressive Matrices scores across time and place. Learning and Individual Differences, 19, 330-338.

Cicchetti, D. \& Valentino, K. (2006). An ecological-transactional perspective on child maltreatment. In D. Cicchetti \& D.J. Cohen (Eds.), Developmental psychopathology (2nd edition): Vol. 3. Risk, disorder, and adaptation (pp. 129-201). Hoboken, NJ: John Wiley $\&$ Sons.

Dubois, E., Młotkowska, H. (1968). Test Matryc: podręcznik tymczasowy [Raven's Progressive Matrices Test: Provisional Manual]. Warszawa: Centralny Ośrodek Pedagogiczny Szkolnictwa Artystycznego.

Flynn, J.R. (1984). The mean IQ of American: Massive gains 1932 to 1978 Psychological Bulletin, 95, 29-51.

Flynn, J. R. (1987). Massive IQ Gains in 14 Nations: What IQ Tests Really Measure. Psychological Bulletin, 101, 171-191

Flynn, J.R. (2007). What is intelligence? Beyond the Flynn effect. Cambridge: Cambridge University Press.

Hornowski B. (1959). Analiza psychologiczna Skali J.C. Ravena [Psychological Analysis of J.C. Raven's Matrices].

Herrnstein, R. J., \& Murray, C. (1994). The Bell Curve: Intelligence and class structure in American life. New York: The Free Press.

Husen, T., \& Tuijnman, A. (1991). The contribution of formal schooling to the increase in intellectual capital. Educational Researcher, 20, $17-25$

Jaffee, S.R., Maikovich-Fong, A.K. (2011). Effects of chronic maltreatment and maltreatment timing on children's behavior and cognitive abilities. Journal of Child Psychology \& Psychiatry, 52, 184-194.

Martorell, R. (1998). Nutrition and the worldwide rise in IQ scores. In: Ulric Neisser (ed.), The rising curve: Long term gains in IQ and related measures (pp. 183-206). Washington, DC, US: American Psychological Association.

Neisser, U. (Ed.). (1998). The rising curve: Long-term gains in IQ and related measures. Washington, DC, US: American Psychological Association.

Nicollet, J.J., Guillen, C.J., Jouhar, A.-Ch., Rossier, J. (2009). Performance aux tests d'intelligence: Vers une Inversion de l'effet Flynn [Intelligence test performance: An inversion of the Flynn effect?] Orientation Scolaire et Professionnelle, 38, 353-368.

Jaworowska, A. (1990). Polskie badania nad Testem Matryc Ravena. [Polish studies on Raven's Progressive Matrices Test]. Przeglad Psychologiczny, 33, 247-258.

Jaworowska, A. Szustrowa, T. (2000). Test Matryc Ravena w wersji Standard. Formy: Klasyczna, Równoległa, Plus. Polskie Standaryzacje. [Raven's Progressive Matrices: Standard, Classica, Parallel and Plus Versions. Polish Standardization.] Warszawa: Pracownia Testów Psychologicznych PTP.

Kalina, W. (1962). Wyniki badań "Progressive Matrices" J. C. Ravena. [Results of Raven's Progressive Matrices Test]. Kultura Fizyczna 3, 219-216.

Lynn, R., Hampson, S. (1986). The rise of national intelligence: Evidence from Britain, Japan and the U.S.A. Personality and Individual Differences, 7, 23-32.

Lynn, R. (2013). Who discovered the Flynn Effect? A review of early studies of the secular increase of intelligence. Intelligence, in press.

Lynn, R. (1990). The role of nutrition in secular increases in intelligence. Personality and Individual Differences, 11, 273-285.

Martorano, B., L. Natali, C. de Neubourg and J. Bradshaw (2013). 'Child Wellbeing in Economically Rich Countries: Changes in the first decade of the 21st century', Working Paper 2013-02. Florence:
UNICEF Office of Research. Available: http://www.unicef-irc.org/ publications/pdf/iwp 2013 2.pdf

Martorell, R. (1998). Nutrition and the worldwide rise in IQ scores. In Ulric Neisser (Ed.), The rising curve: Long term gains in $I Q$ and related measures (pp. 183-206). Washington, DC, US7 American Psychological Association.

Mills, R., Alati, R., O’Callaghan, M., Najman, J.M., Williams, G.M., Bor, W., Strathearn, L. (2011). Child Abuse and Neglect and Cognitive Function at 14 Years of Age: Findings From a Birth Cohort. Pediatrics, 127, 4-10.

OECD (2006). Assessing scientific, reading and mathematical literacy: $A$ framework for PISA 2006. Paris: OECD.

Próchniak M. \& Witkowski B. (2013). Time Stability of the Beta Convergence among EU Countries: Bayesian Model Averaging Perspective. Economic Modeling, 30, 322-333.

Rowe, D.C., Rodgers, J.L. (2002). Expanding Variance and the Case of Historical Changes in IQ Means: A Critique of Dickens and Flynn (2001). Psychological Review, 104, 759-763.

Russel, E.W. (2007). Commentary: The Flynn Effect Revisited. Applied Neuropsychology, 14, 262-266.

Sajkowska, M. (2009). Bicie dzieci. Postawy i doświadczenia dorosłych Polaków. Raport z badan. [Child abuse. Attitudes and experiences of adult Poles. Research report]. Warsaw: Nobody's Children Foundation. Available: http://fdn.pl/badania

Schooler, C. (1998). Environmental complexity and the Flynn effect. In U. Neisser (Ed.), The rising curve: Long term gains in IQ and related measures (pp. 67-79). Washington, DC, US: American Psychological Association.

Smulczyk, M., Haman, J., Pokropek, A. (2013). Organizacja i metodologia badania Ścieżki rozwoju edukacyjnego młodzieży - szkoły pogimnazjalne [Methodology and organisation of study „Paths of educational youth development" - Polish high schools]. In: M. Karwowski (red.). Ścieżki rozwoju edukacyjnego młodzieży szkoły pogimnazjalne. Trafność wskaźników edukacyjnej wartości dodanej dla szkót maturalnych (s. 47-96) [„,Paths of educational youth development" - Polish high schools Validity of education added value for high schools (pp. 47-96)]. Warszawa: Wydawnictwo Instytutu Filozofii i Socjologii PAN.

Sokołowska, M., Firkowska-Mankiewicz, A., Ostrowska, A., Czarkowski, M.P. (1978). Intellectual Performance of Children in the Light of Socio-cultural Factors - Warsaw Study. Warszawa: IFiS PAN.

Strzyżewski, S. (1973). Młodzież bydgoskich szkół podstawowych w świetle Testu Progressive Matrices J.C. Ravena. [Youth of Bydgoszcz primary schools in the light of the results of J. C. Raven's Progressive Matrices Test] Przeglad Psychologiczny, 1, 61-70.

Wicherts, J. M., Dolan, C.V., Hessen, D.J., Oosterveld, P., van Baal. G.C.M., Boomsma., Span, M.M. (2004). Are intelligence test measurements invariant over time? Investigating the nature of the Flynn effect. Intelligence, 32, 509-537.

te Nijenhuis \& van der J., Flier, H. (2007). The secular rise in IQs in the Netherlands: Is the Flynn effect on g? Personality and Individual Differences, 43, 1259-1265.

Teasdale, T. W., \& Owen, D. R. (1989). Continuing secular increases in intelligence and a stable prevalence of high intelligence levels. Intelligence, 13, 255-262.

Tuddenham, R. D. (1948). Soldier intelligence in World Wars I and II. American Psychologist, 3, 54-56.

te Nijenhuis \& van der J., Flier, H. (in press). Is the Flynn effect on g? A meta-analysis. Intelligence.

Zajonc, R. B., \& Mullally, P. R. (1997). Birth order: Reconciling conflicting effects. American Psychologist, 52, 685-699. 